\title{
Analisis dan Pengukuran Kualitas Informasi Pada Website Menggunakan Pendekatan Six Sigma
}

\author{
Bagus Faisal $^{\mathrm{a}}$, Candiwan ${ }^{\mathrm{b} *}$, Yudi Priyadi ${ }^{\mathrm{c}}$ \\ ${ }^{a b c}$ Program Studi Manajemen Bisnis Telekomunikasi dan Informatika, \\ Fakultas Ekonomi dan Bisnis, Universitas Telkom \\ Naskah Diterima : 26 Oktober 2017; Diterima Publikasi : 14 Februari 2018
}

DOI : 10.21456/vol8iss1pp84-91

\begin{abstract}
Information held by a company is one of the important factors for its success. Nowadays with rapid development of usage of internet and social media, bad information can also have a significantly negative impact on every element / level that exists in the company or in the community. Sometimes it can lead to public unrest. Bad or good information has correlation with the quality of information. The aim of this research is to assest and analyze the quality of information using Six Sigma approach and we choose Kaskus website as a case study. Kaskus is the largest community online in Indonesia. It provided various kinds of information to its user. By using its approach, this research consists of 5 stages, they are "define", "measure", "analysis", "improve", and "control". Each phase/stage using different tools to assess the current Information Quality, such as questionnaires for define phase, "Expert Choice"(Analytic Hierarchy Process) for measure phase, and quality function deployment (QFD) for analysis stage. Questionnaires used for defining customer specifications and identify information quality problem, meanwhile software "Expert Choice" used to measure the importance each quality information dimensions and then to validate/analyzise the problem of the data. And lastly, QFD used to determine the mutual relationships of information quality dimensions and critical to Information Quality factors. Output of "Analyze" stage shows that Accuracy, Relevancy, and Objectivity dimension on Kaskus website need to be improved immediately because it reaches unacceptable point.
\end{abstract}

Keywords: Information Quality; Information Quality Assessment; Six Sigma; Analytic Hierarchy Process (AHP); Quality Function Deployment (QFD)

\begin{abstract}
Abstrak
Informasi yang dimiliki oleh perusahaan merupakan salah satu faktor penting untuk keberhasilan. Pesatnya perkembangan penggunaan media internet dan media sosial saat ini, informasi yang buruk juga secra signifikan dapat berdampak negatif terhadap setiap elemen/tingkatan yang ada di perusahaan atau di masyarakat. Terkadang informasi tersebut bisa menimbulkan keresahan masyarakat. Buruk atau baiknya informasi berkorelasi dengan kualitas informasi. Tujuan dari penelitian ini adalah untuk mengetahui dan menganalisis kualitas informasi dengan menggunakan pendekatan Six Sigma dan kami memilih situs Kaskus sebagai studi kasus. Kaskus adalah komunitas online terbesar di Indonesia dan memberikan berbagai macam informasi kepada penggunanya. Dengan menggunakan pendekatan Six Sigma, penelitian ini melputi 5 tahap, yaitu "define", "measure", "analysis", "improve", and "control". Setiap fase / tahapan menggunakan tools yang berbeda untuk menilai Kualitas Informasi saat ini, seperti kuesioner untuk tahap pendefinisian, "Expert Choice" (Analytic Hierarchy Process) untuk tahap pengukuran, dan Quality Function Deployment (QFD) untuk tahap analisis. Kuesioner yang digunakan untuk mendefinisikan spesifikasi pelanggan dan mengidentifikasikan masalah kualitas informasi, sementara software "Expert Choice" digunakan untuk mengukur pentingnya masing-masing dimensi kualitas informasi dan memvalidasi / menganalisis masalah data. Dan yang terakhir, QFD digunakan untuk menentukan hubungan timbal balik kualitas informasi dan penting untuk faktor dimensi Kualitas Informasi. Output dari tahap "analysis" menunjukkan bahwa dimensi Kebenaran, Relevansi, dan Objektivitas pada website Kaskus perlu segera ditingkatkan karena mencapai titik tidak dapat diterima.
\end{abstract}

Keywords: Kualitas Informasi; Pengukuran Kualitas Informasi; Six Sigma; Analytic Hierarchy Process (AHP); Quality Function Deployment (QFD)

\section{Pendahuluan}

Kaskus sebagai komunitas online terbesar di Indonesia memiliki lebih dari 7,8 juta anggota memegang begitu banyak informasi dari anggotanya dari berbagai forum yang telah dibuat (Aziz, 2014).

\footnotetext{
*) Penulis korespondensi: bagus_faisal@ rocketmail.com
}

Melalui forum tersebut, setiap anggota bebas mengekspresikan pendapat mereka dan menulis thread apapun. Hal ini menyebabkan terlalu banyak informasi yang beredar, Kaskus perlu mengelola kualitas informasi mereka karena memiliki dampak yang sangat besar tidak hanya untuk Kaskus sendiri, 
tapi juga bagi penggunanya. Salah satu kasus penipuan yang mengejutkan tidak hanya untuk pengguna Kaskus, tapi juga setiap pengguna internet di Indonesia adalah "Blackpanda". Blackpanda adalah organisasi yang menangani akun bersama untuk memastikan bahwa transaksi online dapat tetap aman bagi kedua belah pihak (pembeli dan penjual). Kegagalan Kaskus untuk mengamankan akun bersama yang telah menjadi solusi untuk transaksi online membuat penggunanya bertanya mengenai kualitas informasi website Kaskus (Jamaludin, 2015). Apalagi praktik plagiarisme di situs Kaskus yang sepertinya diijinkan oleh Kaskus sendiri memperparah kualitas informasinya (Gardhadipura, 2015). Selain itu, kualitas informasi Kaskus diperburuk dengan berita penipuan yang bisa saja muncul setiap saat karena anggota yang tidak bertanggung jawab secara bebas menyebarkan informasi yang tidak benar di forum mereka (Grafelly, 2016). Dengan demikian, mengelola dan menilai kualitas informasi dan kemudian memastikan perbaikannya secara terus menerus adalah suatu keharusan dan perlu segera dilakukan.

Lee et al. (2011) mengatakan bahwa sebagian besar kerangka kerja penilaian kualitas informasi yang tersedia didasarkan pada pengukuran data pelanggan saja dan oleh karena itu, kerangka kerja tersebut tidak memberikan penilaian kualitas informasi yang komprehensif dan sistematis. Bagaimanapun, pendekatan ini tidak hanya tidak mampu memberikan pengukuran lengkap terhadap semua dimensi kualitas informasi, tetapi juga tidak dapat menyoroti ketidaksesuaian data karena korelasi berbagai dimensi kualitas informasi. Oleh karena itu, Information Quality Assesment (IQ Assessment) menggunakan pendekatan Six Sigma dapat menghasilkan hasil penilaian yang akurat, sistematis, dan pragmatis. Petter et al. (2008) menunjukkan bahwa faktor keberhasilan dalam mengevaluasi sistem informasi adalah kualitas informasi dan kepuasan pengguna. Ini menunjukkan bahwa IQ Assesment harus memperhatikan perspektif kualitas produk dan layanan.

Pembuatan thread (forum) baru-baru ini oleh anggota Kaskus tanpa proses editing sebelumnya, dapat menyebabkan kualitas informasi menurun dan tidak terkendali. Lemahnya dan tidak terkendalinya kualitas informasi dapat menyebabkan masalah besar dikemudian hari, sehingga perlu diatur dengan baik seperti asset lainnya. Untuk mengatur kualitas informasi secara efektif dan efisien, hal ini membutuhkan pengukuran dan penilaian sesuai dengan informasi yang ada. Six Sigma adalah sebuah pendekatan yang digunakan untuk meningkatkan efektifitas dan efisiensi semua operasi untuk memenuhi atau melampaui kebutuhan dan harapan pelanggan (Kwak dan Anbari, 2006). Hal tersebut berguna untuk mengevaluasi kemampuan proses dalam melakukan pembebasan kecacatan, dimana kecacatan tersebut didefinisikan sebagai sesuatu yang menghasilkan ketidakpuasan pelanggan (Black dan Revere, 2006). Information Quality Assesment dalam penelitian sebelumnya menggunakan pendekatan Six Sigma terbukti sistematis dan efektif (Lee et al., 2011). Berdasarkan uraian di atas, peneliti memilih judul "Analisis dan Penilaian Kualitas Informasi pada Website Menggunakan Pendekatan Six Sigma (Studi Kasus Website Kaskus)" sebagai penelitian.

\section{Kerangka Teoritis}

Menurut Gasperz (2011), Six Sigma adalah suatu metode terstruktur yang dapat diintepretasikan dalam lima tahapan, diantaranya:

1. Define: Implementasi dari tahap ini, tim akan mengidentifikasi masalah, menentukan waktu target, menentukan spesifikasi pelanggan (critical to quality), menentukan dan menjelaskan $Q C$ flow chart serta menentukan tujuan yang ingin dicapai.

2. Measure: Tahap ini bertujuan untuk memvalidasikan masalah, mengukur atau menganalisa masalah data - existing data.

3. Analyze: Pada tahap ini akan ditentukan faktor apa saja yang mempengaruhi suatu proses. Ini berarti bahwa jika ada tiga faktor dasar, maka koreksi kualitas akan meningkat secara signifikan.

4. Improve: Tahap ini akan membahas dan membicarakan tentang ide untuk melakukan perbaikan berdasarkan analisis yang telah dilakukan. Tahap ini juga melakukan percobaan untuk melihat hasilnya apakah hal tersebut efektif atau tidak. Jika hasilnya efektif, bisa distandarisasikan menjadi Standard Operating Procedure (SOP).

5. Control: Setelah tahap keempat di atas telah selesai, langkah selanjutnya adalah membuat rencana dan desain hasil pengukuran perbaikan yang telah dilakukan dalam rangka untuk mengontrol dan memonitori secara berkelanjutan. (Kelima tahap Six Sigma dapat dilihat pada Gambar 1).

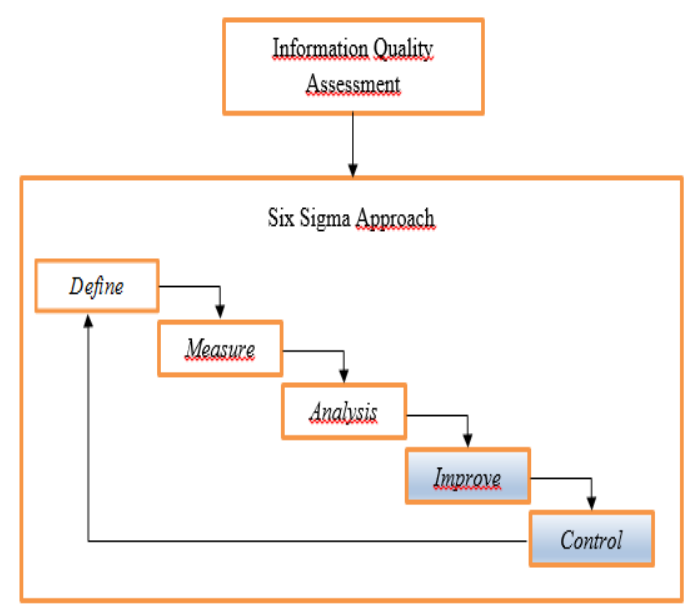

Gambar 1. Model penelitian pendekatan Six Sigma 
Menurut Lee et al. (2011), Information Quality Assesment menggunakan pendekatan Six Sigma terdiri dari 5 fase (tahap) yaitu define, measure, analisys, improve, dan control. Masing-masing fase memiliki tujuan yang berbeda dan pada akhirnya tujuan tersebut bergabung menjadi sauatu aset dan analisis kualitas informasi pada website Kaskus. Fase define akan mengidentifikasi masalah, menentukan target, dan mendefinisikan spesifikasi pelanggan sebagai informasi utama untuk mengetahui kualitas informasi saat ini. Fase measure bertujuan untuk memvalidasi masalah dan mengukur atau menganalisa masalah data untuk mengetahui dimensi kualitas informasi yang lebih penting daripada yang lain untuk pengguna Kaskus dan Kaskus itu sendiri. Selanjutnya fase analisys menentukan hubungan timbal balik dimensi kualitas informasi dan faktor penting untuk kualitas informasi. Untuk mengambil pendekatan pragmatis, Madnick et al. (2009) membagi IQ Framework menjadi dua perspektif: topic dan metode. Karena penerapan bermacam-macam IQ, merencanakan untuk membangun kerangka kerja kualitas harus terlebih dahulu menetapkan komponen, dimensi dan metode apa saja yang dimasukkan ke dalam kerangka kerja dari berbagai aspek IQ. Penelitian dimensi IQ sebelumnya diupayakan untuk mengelompokkan dan mengidentifikasikan informasi dalam memperoleh pemahaman informasi dan memahami atributatributnya.

Terdapat lima tahapan Six Sigma pada Gambar 1, fase improve dan fase control harus dilakukan dalam batasan-batasan organisasi, untuk tahap ini melibatkan persyaratan teknis dan action. Karena penelitian ini hanya akan menjelaskan hingga tahap analisis saja, dan sisanya akan dijelaskan sebagai rekomendasi

Menurut Naumann dan Rolker (2000), kualitas informasi dipengaruhi oleh tiga faktor penting yaitu informasi umpan balik pengguna (kriteria subjek), sumber informasi (kriteria objek), dan proses pengaksesan informasi (kriteria proses). Dalam pelaksanaannya, untuk ketiga kriteria tersebut, masing-masing memiliki beberapa dimensi kualitas informasi yang dikategorikan ke dalam beberapa kriteria (IQ criteria).

Sementara itu Lee et al. (2011) menyebutkan kriteria untuk dimensi kualitas informasi dari perspektif kualitas produk dan layanan, dan dengan demikian kriteria dimensi untuk Information Quality Assessment ditunjukkan pada Gambar 2.

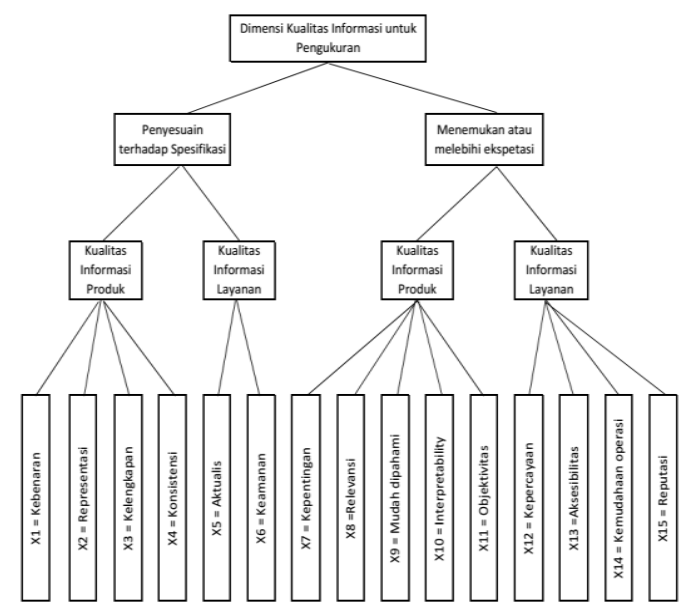

Gambar 2. Dimensi kualitas informasi

Menurut Lee et al. (2012), dimensi kualitas informasi dapat bergantung pada konteks yang dependen dan konteks yang independen, dan dapat ditafsirkan dengan cara yang berbeda sesuai dengan jenis penggunaan informasi dan peraturan bisnis yang berbeda. Misalnya, kualitas layanan sebagai konteks yang dependen dan terdiri dari keamanan dan aktualitas sebagai konteks yang independen.

Berdasarkan Gambar 2, lima belas dimensi IQ dipilih untuk penelitian ini adalah kebenaran, representasi, kelengkapan, konsistensi, aktualitas, keamanan, kepentingan, relevansi, mudah dipahami, kemampuan Interpretability, objektivitas, kepercayaan, aksesibilitas, kemudahan pengoperasian, dan reputasi.

Pada penelitian ini, berdasarkan pendekatan Six Sigma yang digunakan sampai tahap analisis, hasil tahap sebelumnya, yaitu fase define dan fase measure dikombinasikan dengan menggunakan Quality Function Deployment (QFD) sebagai tools untuk menentukan dimensi mana yang buruk dan perlu dilakukan fase Improve.

Dalam penelitian ini, matriks kebutuhan pelanggan diganti dengan umpan balik pengguna yang telah dikumpulkan, sedangkan matriks persyaratan teknis diwakili oleh hirarki dimensi kualitas informasi. Ada deskripsi lengkap tentang Quality Function Deployment di dalam Information Quality Assessment seperti yang ditunjukkan pada Gambar 3 . 


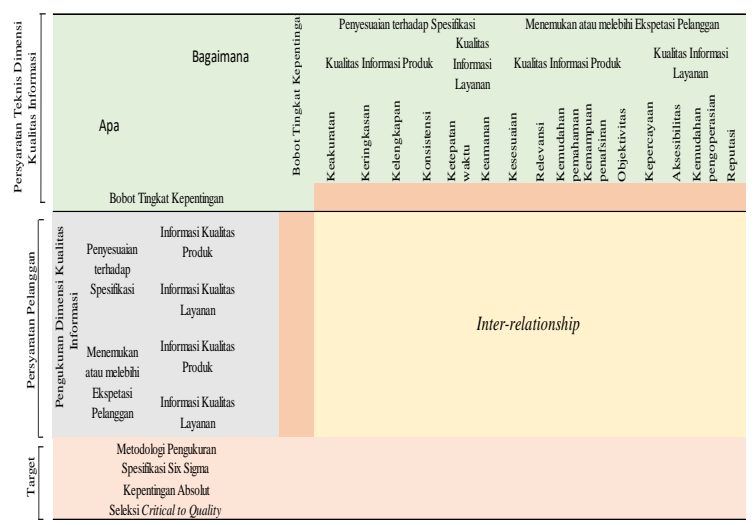

Gambar 3. Quality Function Deployment (QFD)

Menurut Lee et al. (2012), 3-dimensional quality yang memiliki nilai tertinggi bisa dikatakan buruk dan harus dilakukan langkah perbaikan pada dimensi tersebut.

\section{Metode}

Metode yang digunakan di dalam penelitian ini adalah metode kuantitatif. Menurut Sugiyono (2011), metode kuantitatif adalah pendekatan ilmiah yang memandang suatu realitas itu dapat diklasifikasikan, konkrit, teramati dan terukur, serta hubungan variabelnya bersifat sebab akibat dimana data penelitiannya berupa angka-angka dan analisisnya menggunakan statistik. Sedangkan tujuan penelitian ini bersifat deskriptif yaitu menilai dan menjabarkan kualitas informasi yang ada di situs Kaskus.

Berdasarkan waktu pelaksanaan, penelitian ini menggunakan metode cross sectional. Menurut Indrawati (2015), cross sectional merupakan pengumpulan data yang dilakukan dalam satu periode, kemudian data tersebut diolah, dianalisis, dan kemudian ditarik kesimpulan. Tahapan penelitian dapat dilihat pada Gambar 4.

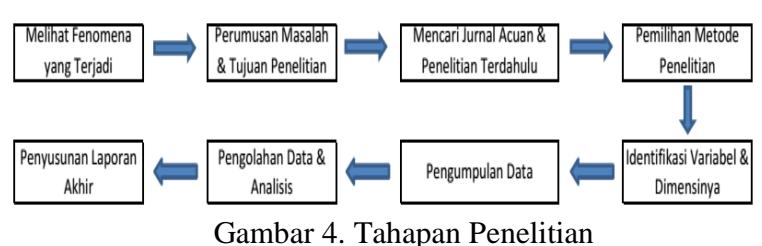

Pada penelitian ini, peneliti memilih Kaskus sebagai objek penelitiannya. Kaskus merupakan forum komunitas maya terbesar di Indonesia dengan lebih dari 530 kategori pada forumnya dan lebih dari 8 juta anggota (Jeko, 2015). Besarnya jumlah angguta Kaskus diperkirakan ini masih akan terus meningkat karena pada tahun sebelumnya jumlah anggota telah mencapai lebih dari 7,8 juta anggota (Aziz, 2014).

Setelah menentukan objek penelitian, hal yang pertama dilakukan oleh peneliti dalam memulai penelitian adalah melihat fenomena yang terjadi di Kaskus. Setelah itu, dibuatlah perumusan masalah dan tujuan penelitian yang akan dilakukan. Untuk mendukung dan memudahkan penelitian, peneliti mulai mencari referensi berupa penelitian terdahulu, jurnal (nasional \& internasional) dan tinjauan pustaka yang sesuai dengan topik yang di angkat. Melalui pembelajaran tersebut, peneliti memilih six sigma sebagai metode terpilih dan mempelajari sampel untuk pengumpulan data. Dengan mempelajari sampel, peneliti akan dapat membuat kesimpulan yang bisa digeneralisasikan populasi dari penelitian ini.

Menurut Indrawati (2015), sampel yang dipilih mendekati karakteristik populasi, sehingga teknik sampling yang digunakan juga harus mempertimbangkan representasi dalam sampel populasi, sehingga peneliti menggunakan probability sampling, teknik pengambilan sampel yang memungkinkan anggota populasi memiliki kesempatan atau probabilitas yang sama. untuk dipilih sebagai sampel. Populasi dalam penelitian ini adalah orang yang menggunakan Layanan Kaskus atau orang yang menjadi anggota Kaskus di Indonesia.

Berdasarkan pendekatan di atas dan dengan mempertimbangkan jumlah pengguna Kaskus yang tidak tercatat secara khusus dan terus bertambah, ukuran sampel minimal untuk penelitian deskriptif adalah 100 responden (Uma, 2011). Pada penelitian ini, peneliti menggunakan 108 responden. Setelah data terkumpul, proses pengolahan data dan analisis data dilakukan melalui empat tahapan six sigma yaitu define, measure, analysis, dan improve. Sebelum data dianalisis (yakni tahap measure), data diuji menggunakan metode AHP.

Namun pada metode AHP ini, untuk uji validitas dan reliabilitas dilakukan dengan uji konsistensi, karena input masukan pada metode ini berupa tanggapan bebas, sehingga hanya dilakukan uji konsistensi saja. Menurut Kusumadewi (2006), uji konsistensi AHP dapat dilakukan dengan mengikuti Persamaan (1) :

$\frac{C I}{R I_{n}} \leq 0,1$

dimana RI = "Random Index" AHP, dengan CI diketahui, menggunakan Persamaan (2):

$C I=\frac{t-n}{n-1}$

dimana $\mathrm{n}$ adalah jumlah elemen/hierarki, dan $\mathrm{t}$ dapat ditemukan dengan menggunakan Persamaan (3) :

$t=\frac{1}{n} \sum_{i=1}^{n}\left(\frac{\text { elemen }-i \text { on }(A)\left(w^{T}\right)}{\text { elemen }-i \text { on } w^{T}}\right.$

dimana:

A = Persamaan Matriks

$\mathrm{w}=$ Bobot Vektor Matriks AHP

Dengan menggunakan software Expert Choice, uji konsistensi perhitungan hirarki AHP dapat dilakukan secara otomatis. Setelah itu, data dianalisis 
menggunakan Quality Function Deployment (QFD) sebagai tools untuk mengetahui dimensi mana yang buruk dan perlu dilakukannya tahap improve selanjutnya.

\section{Hasil dan Pembahasan}

\subsection{Karakteristik Data Responden}

Penelitian ini dilakukan pada bulan Januari 2016 dan jumlah responden sebanyak 108 orang, karakteristik responden ditunjukan pada Tabel 1 dan Tabel 2.

Berdasarkan data yang disajikan pada Tabel 1, karakteristik responden yang paling dominan adalah laki-laki berumur 21-25 tahun yang berstatus seorang mahasiswa. Banyaknya responden yang mengaku bahwa pernah mengakses situs Kaskus namun tidak menjadi user terdaftar menunjukkan bahwa sebagian besar pengguna Kaskus adalah mereka yang hanya mencari informasi di situs tersebut, bukan pembuat informasinya. Selain itu, dapat diketahui juga jumlah responden yang mengakses website Kaskus dan frekuensi responden mengkses website Kaskus yang mana jumlah tersebut dapat dilihat pada Tabel.2.

Tabel 1. Karakteristik Responden

\begin{tabular}{cccc}
\hline No & Item & $\begin{array}{c}\text { Jumlah } \\
\text { Responden }\end{array}$ & Persentase \\
\hline 1. & Jenis Kelamin & 72 & 66.7 \\
a. & Pria & 36 & 33.3 \\
b. & Wanita & & \\
2 & Tipe Pengguna & 60 & 55.6 \\
a. & Terdaftar & 48 & 44.4 \\
b. & Tidak Terdaftar & & \\
3. & Umur Pengguna & 45 & 41.7 \\
a. & 15-20 tahun & 62 & 57.4 \\
b. & 21-25 tahun & 1 & 0.9 \\
c. & 26-30 tahun & 0 & 0.0 \\
d. & 31-35 tahun & 0 & 0.0 \\
e. & 36-40 tahun & 0 & 0.0 \\
f. & . 40 tahun & & \\
4. & Pekerjaan Pengguna & 2 & 1,9 \\
a. & Pelajar & 94 & 87 \\
b. & Mahasiswa & 0 & 0 \\
c. & Pegawai Negeri & 9 & 8,3 \\
d. & Swasta & 2 & 1,9 \\
e. & Wiraswasta & 1 & 0,9 \\
f. & Lainnya & &
\end{tabular}

Tabel 2. Karakteristik responden berdasarkan periode waktu dan frekuensi akses

\begin{tabular}{cccc}
\hline No & Item & Jumlah Responden & Persentase \\
\hline 1. & Periode & & \\
a. & Penggunaan & 23 & \\
b. & $6-12$ bulan & 9 & 21,30 \\
c. & $>1$ tahun & 76 & 8,33 \\
2. & Frekuensi Akses & & 70,37 \\
a. & 1 kali per hari & 23 & \\
b. & 1 kali per minggu & 37 & 21,30 \\
c. & 1 kali per bulan & 31 & 34,26 \\
d. & 1 kali per tahun & 17 & 28,70 \\
\hline
\end{tabular}

Berdasarkan Tabel 2 diatas, dapat dilihat bahwa reponden rata-rata frekuensi mengakses situs Kaskus setidaknya 1 kali dalam seminggu dan lama menjadi pengguna Kaskus lebih dari 1 tahun, hal ini menunjukkan bahwa situs Kaskus sudah menjadi sumber informasi yang seringkali digunakan oleh para responden dan sudah menjadi kebiasaan untuk mengakses situs tersebut.

Dari pernyataan diatas dapat disimpulkan bahwa pengguna Kaskus lebih cenderung loyal terhadap Kaskus, mengingat Kaskus adalah adalah situs komunitas online pertama di Indonesia yang dikenal luas oleh masyarakat. Namun demikian, dari sekian banyaknya pengguna Kaskus, sebagian besar pengguna masih enggan untuk membuat sendiri thread atau informasi baru pada situs tersebut. Mereka hanya sekedar mencari informasi atau sekedar "berselancar" pada situs tersebut. Sedangkan pembuat thread/ forum baru adalah "pemain-pemain lama” pada situs Kaskus.

\subsection{Define Stage}

Tahap "Define" akan mengidentifikasi masalah, menentukan target, dan menentukan spesifikasi pelanggan dengan menggunakan kuesioner sebagai tools. Kuesioner akan disebar pada lebih dari 100 responden, yaitu pengguna informasi di Kaskus. Output kuesioner pada akhirnya akan mempengaruhi dimensi kualitas informasi dan ditunjukkan sebagai berikut :

Tabel 3. Permasalahan IQ dan pengaruhnya terhadap dimensi IQ

\begin{tabular}{|c|c|c|c|}
\hline $\begin{array}{l}\text { Permasalahan } \\
\text { IQ }\end{array}$ & $\begin{array}{c}\text { Dimensi yang } \\
\text { dipengaruhi oleh } \\
\text { permasalahan IQ }\end{array}$ & $\begin{array}{l}\text { Permasalahan } \\
\text { IQ }\end{array}$ & $\begin{array}{c}\text { Dimensi yang } \\
\text { dipengaruhi oleh } \\
\text { permasalahan IQ } \\
\end{array}$ \\
\hline $\begin{array}{l}\text { Tidak dapat } \\
\text { dipercaya }\end{array}$ & $\begin{array}{c}\mathrm{X} 1, \mathrm{X} 6, \mathrm{X} 8, \mathrm{X} 12 \\
\mathrm{X} 15\end{array}$ & Tidak aman & $\mathrm{X} 6, \mathrm{X} 15$ \\
\hline $\begin{array}{l}\text { Bias dan tidak } \\
\text { jelas }\end{array}$ & $\mathrm{X} 3, \mathrm{X} 9, \mathrm{X} 10, \mathrm{X} 11$ & $\begin{array}{l}\text { Tidak tepat } \\
\text { waktu }\end{array}$ & $\mathrm{X} 4, \mathrm{X} 5, \mathrm{X} 8$ \\
\hline Tidak sesuai & $\begin{array}{l}\mathrm{X} 1, \mathrm{X} 2, \mathrm{X} 4, \mathrm{X} 8 \\
\mathrm{X} 12\end{array}$ & $\begin{array}{l}\text { Tidak dapat } \\
\text { dipertanggung } \\
\text { jawabkan }\end{array}$ & $\begin{array}{c}\mathrm{X} 1, \mathrm{X} 4, \mathrm{X} 8, \mathrm{X} 11, \\
\mathrm{X} 12\end{array}$ \\
\hline $\begin{array}{l}\text { Sulit } \\
\text { dipahami }\end{array}$ & $\mathrm{X} 9, \mathrm{X} 10, \mathrm{X} 14$ & $\begin{array}{l}\text { Tidak tepat } \\
\text { sasaran }\end{array}$ & $\mathrm{X} 7, \mathrm{X} 8$ \\
\hline $\begin{array}{l}\text { Reputasi yang } \\
\text { buruk }\end{array}$ & $\mathrm{X} 12, \mathrm{X} 15$ & $\begin{array}{l}\text { Ukuran data } \\
\text { terlalu besar }\end{array}$ & $\mathrm{X} 3, \mathrm{X} 7, \mathrm{X} 11$ \\
\hline Tidak bernilai & $\mathrm{X} 1, \mathrm{X} 5, \mathrm{X} 7, \mathrm{X} 8$ & $\begin{array}{l}\text { Tidak selalu } \\
\text { tersedia }\end{array}$ & $\mathrm{X} 5, \mathrm{X} 13, \mathrm{X} 14$ \\
\hline Tidak lengkap & $\mathrm{X} 2, \mathrm{X} 3, \mathrm{X} 11$ & $\begin{array}{l}\text { Informasi } \\
\text { tidak } \\
\text { konsisten }\end{array}$ & $\mathrm{X} 2, \mathrm{X} 4, \mathrm{X} 11$ \\
\hline $\begin{array}{l}\text { Tidak } \\
\text { mendukung } \\
\text { konsumen }\end{array}$ & $\begin{array}{c}\mathrm{X} 6, \mathrm{X} 10, \mathrm{X} 13, \\
\mathrm{X} 14\end{array}$ & $\begin{array}{l}\text { Lama dalam } \\
\text { pemrosesan }\end{array}$ & $\mathrm{X} 13, \mathrm{X} 14$ \\
\hline $\begin{array}{l}\text { Tidak ada } \\
\text { dokumentasi }\end{array}$ & X3, X5, X13, X14 & $\begin{array}{l}\text { Tidak } \\
\text { responsif }\end{array}$ & $\mathrm{X} 1, \mathrm{X} 5, \mathrm{X} 8, \mathrm{X} 10$ \\
\hline $\begin{array}{l}\text { Tidak dapat } \\
\text { diandalkan }\end{array}$ & $\begin{array}{c}\mathrm{X} 1, \mathrm{X} 7, \mathrm{X} 8, \mathrm{X} 11, \\
\mathrm{X} 15\end{array}$ & & \\
\hline \multicolumn{4}{|c|}{$\begin{array}{l}\text { eterangan: } \\
\text { ebenaran (X1), representasi (X2), kelengkapan (X3), } \\
\text { onsistensi (X4), aktualitas (X5), keamanan (X6), } \\
\text { epentingan (X7), relevansi (X8), mudah dipahami (X9), } \\
\text { terpretability (X10), objektivitas (X11), kepercayaan } \\
\text { X12), aksesibilitas (X13), kemudahan pngoperasian (X14), } \\
\text { an reputasi (15). }\end{array}$} \\
\hline
\end{tabular}




\subsection{Measure Stage}

Tahap ini bertujuan untuk memvalidasi masalah, mengukur, atau menganalisa masalah data. Oleh sebab itu, informasi yang dikumpulkan dari tanggapan pada bagian pair-wise comparisons dalam survei disusun dan Analytic Hierarchy Process (AHP) diterapkan pada data yang dikumpulkan. Menurut Kusumadewi (2006), AHP adalah model pendukung keputusan yang dapat menguraikan beberapa faktor kompleks menjadi kriteria sederhana. Hasil perhitungan AHP untuk penelitian ini dapat dilihat pada Tabel 4.

Tabel 4 mengilustrasikan hasil pengukuran dimensi kualitas informasi yang mana pengukuran tersebut dilakukan dengan metode AHP. Hasil survei menunjukkan "kesesuaian dengan spesifikasi" $(0,356)$ lebih rendah daripada "memenuhi atau melampaui harapan pelanggan" (0.644). Bukan tidak beralasan untuk menyatakan bahwa Kaskus sebagai situs komunitas online sedikit lebih menekankan pada perspektif subjektif informasi. Sementara "informasi kualitas produk" selalu menjadi masalah karena perspektif informasi subjektif, sehingga tidak mengherankan bahwa "kualitas informasi produk" memiliki bobot lebih tinggi di kedua sisi (sesuai dengan spesifikasi dan memenuhi atau melebihi harapan pelanggan).

Tabel 4. Ringkasan hasil AHP yang diterapkan pada kaskus

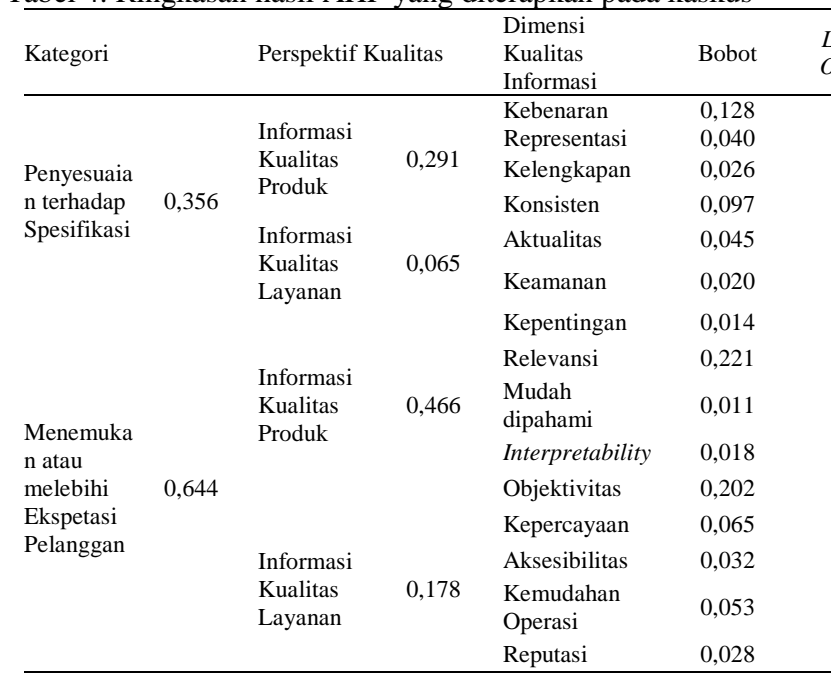

Tabel 4 mengilustrasikan hasil pengukuran dimensi kualitas informasi yang mana pengukuran tersebut dilakukan dengan metode AHP. Hasil survei menunjukkan "kesesuaian dengan spesifikasi" $(0,356)$ lebih rendah daripada "memenuhi atau melampaui harapan pelanggan" (0.644). Bukan tidak beralasan untuk menyatakan bahwa Kaskus sebagai situs komunitas online sedikit lebih menekankan pada perspektif subjektif informasi. Sementara "informasi kualitas produk" selalu menjadi masalah karena perspektif informasi subjektif, sehingga tidak mengherankan bahwa "kualitas informasi produk" memiliki bobot lebih tinggi di kedua sisi (sesuai dengan spesifikasi dan memenuhi atau melebihi harapan pelanggan).

Pengukuran AHP ini digunakan untuk mengetahui secara pasti dimensi kualitas informasi mana yang lebih penting daripada yang lainnya dengan menggunakan tanggapan pengguna sesuai dengan fase "define". Artinya semakin banyak masalah yang mempengaruhi dimensi kualitas informasi semakin sadar penggunanya dan semakin penting dimensi tersebut bagi pengguna Kaskus (Petter et al., 2008).

\subsection{Analysis Stage}

Tujuan utama pada langkah ini adalah untuk memverifikasi dan mengidentifikasi akar penyebab masalah IQ. Oleh karena itu, mencari tahu bagaimana informasi dapat menjadi kekurangan dalam sistem informasi dan mengetahui faktor-faktor penting kualitas harus dilakukan dengan menggunakan Quality Function Deployment (QFD). QFD merupakan hasil penting dari tahap ini. House of Quality (HOQ) adalah inti dari QFD. Di sini, matriks persyaratan pelanggan diganti dengan customer responses yang dikumpulkan dari tahap 1 kerangka kerja Pengukuran IQ. Persyaratan teknis, yang terkait dengan matriks aturan bisnis direpresentasikan di dalam hierarki dimensi IQ sesuai dengan kerangka penilaian IQ fase "define". Inter-relationships matrix dihitung sesuai dengan hasil AHP dalam kerangka Lpenilaian IQ fase "measure". Akhirnya, dalam Ordertriks target, ukuran objektif atau subyektif dan spesifikasi tingkat Six Sigma didefinisikan masingm̧asing dimensi IQ. 2 Tabel 5. Hasil analisis QFD Kaskus

\begin{tabular}{cclcc}
\hline \multicolumn{2}{c}{ No. } & \multicolumn{1}{c}{ Atribut } & $\begin{array}{c}\text { Kepentingan } \\
\text { Absolut }\end{array}$ & $\begin{array}{c}\text { Seleksi } \\
\text { Critical to } \\
\text { Quality }\end{array}$ \\
\hline 1 & 1 & Kebenaran & 2,176 & 3 \\
5 & 2 & Representasi & 0,400 & 8 \\
3 & 3 & Kelengkapan & 0,260 & 11 \\
2 & 4 & Konsistensi & 1,358 & 4 \\
1 & 6 & Aktualitas & 0,585 & 7 \\
3 & 7 & Keamanan & 0,160 & 13 \\
2 & 8 & Relevansi & 0,098 & 14 \\
4 & 9 & Pemahaman & 4,641 & 1 \\
4 & 10 & Interpretability & 0,055 & 15 \\
& 11 & Objektivitas & 0,162 & 12 \\
& 12 & Kepercayaan & 4,040 & 2 \\
& 13 & Aksesibilitas & 0,780 & 5 \\
& 14 & Kemudahan operasi & 0,320 & 9 \\
& 15 & Reputasi & 0,636 & 6 \\
\hline
\end{tabular}

Tiga nilai tertinggi QFD adalah relevansi, objektivitas, dan kebenaran yang perlu segera diperbaiki. Besarnya nilai QFD disebabkan oleh masalah IQ yang telah dirasakan oleh responden yang mempengaruhi dimensi kualitas informasi yang paling penting. Ini menciptakan Critical to Qualtity (CTQ). Tiga pertama nilai CTQ yang tertinggi adalah Relevansi (4,641), Objektivitas $(4,040)$ dan Kebenaran (2,176). Dibandingkan dengan penelitian lain (Islam et al., 2007), informasi yang akurat mendapatkan peringkat tertinggi setelah memperbarui 
informasi tepat waktu sebagai salah satu kebutuhan pelanggan. Ini membuktikan bahwa kebenaran merupakan faktor penting dalam menentukan kualitas informasi.

Faktor-faktor yang mempengaruhi Relevansi sebagai jumlah CTQ tertinggi adalah sebagai berikut (dari yang tertinggi sampai yang terendah): "informasi tidak dapat dipertanggungjawabkan", "informasi tidak dapat dipercaya", "informasi tidak responsif", "informasi tidak tepat sasaran", "informasi tidak tepat waktu", "informasi tidak dapat diandalkan", dan "informasi tidak sesuai" dan "informasi tidak bernilai". Hal ini dapat dilihat pada Tabel 6. Ini berarti dengan menyempurnakan informasi yang tidak dapat dipertanggungjawabkan dan informasi tidak dapat dipercaya, maka kualitas dapat ditingkatkan untuk memperbaiki relevansi informasi Kaskus.

Sedangkan faktor yang mempengaruhi objektivitas adalah sebagai berikut (dari yang tertinggi sampai yang terendah): "informasi tidak dapat dipertanggungjawabkan", "informasi tidak konsisten", "informasi tidak lengkap", dan "informasi bias dan tidak jelas". Hal ini dapat dilihat pada Tabel 6. Dengan memperbaiki informasi tidak dapat dipertanggungjawabkan dan informasi yang tidak konsisten, hal ini dapat menyebabkan peningkatan objektivitas informasi Kaskus.

Tabel 6. CTQ dari QFD

\begin{tabular}{|c|c|c|c|}
\hline Uraian & $\begin{array}{l}\text { Relevans } \\
\quad \mathrm{i} \\
\text { Informas } \\
\mathrm{i}\end{array}$ & $\begin{array}{l}\text { Objektivita } \\
\text { s Informasi }\end{array}$ & $\begin{array}{c}\text { Kebenara } \\
\mathrm{n} \\
\text { Informasi }\end{array}$ \\
\hline $\begin{array}{l}\text { Informasi tidak } \\
\text { responsif }\end{array}$ & 0,38 & 0,88 & \\
\hline $\begin{array}{l}\text { Informasi tidak dapat } \\
\text { dipertanggungjawabk } \\
\text { an }\end{array}$ & 0,64 & 0,22 & 1,01 \\
\hline $\begin{array}{l}\text { Informasi tidak dapat } \\
\text { diandalkan }\end{array}$ & 0,26 & 0,44 & 0,404 \\
\hline $\begin{array}{l}\text { Informasi tidak } \\
\text { bernilai }\end{array}$ & 0,13 & 1,11 & \\
\hline $\begin{array}{l}\text { Informasi tidak } \\
\text { lengkap }\end{array}$ & 0,26 & & 0,606 \\
\hline $\begin{array}{l}\text { Informasi tidak dapat } \\
\text { dipercaya }\end{array}$ & 0,51 & 0,66 & \\
\hline $\begin{array}{l}\text { Informasi tidak } \\
\text { mendukung pengguna }\end{array}$ & & 0,44 & \\
\hline $\begin{array}{l}\text { Informasi tidak tepat } \\
\text { waktu }\end{array}$ & & 0,44 & \\
\hline Informasi tidak sesuai & & 0,44 & \\
\hline $\begin{array}{l}\text { Informasi bias dan } \\
\text { tidak jelas }\end{array}$ & & & 0,606 \\
\hline $\begin{array}{l}\text { Ukuran data informasi } \\
\text { terlalu besar }\end{array}$ & & & 0,404 \\
\hline $\begin{array}{l}\text { Informasi tidak } \\
\text { konsisten }\end{array}$ & & & 1,01 \\
\hline
\end{tabular}

Selain itu, faktor-faktor signifikan yang mempengaruhi kebenaran adalah sebagai berikut (dari yang tertinggi sampai yang terendah): "informasi tidak dapat dipertanggungjawabkan", "informasi tidak dapat dipercaya", dan "informasi tidak responsif"
(Tabel 6). Dengan memperbaiki faktor-faktor ini, kebenaran informasi Kaskus bisa menjadi lebih baik.

Berdasarkan hasil analisis di atas, mayoritas responden mengatakan bahwa "informasi tidak berdasarkan fakta", "informasi adalah informasi yang tidak konsisten", "informasi tidak dapat dipercaya" dan "informasi tidak responsif" secara aktif mempengaruhi dimensi kualitas informasi yang menyebabkan Relevansi, Kebenaran, dan Objektivitas memiliki nilai CTQ yang tinggi. Berbeda dengan Lee et al. (2012) yang menyatakan bahwa kepercayaan sebagai salah satu dimensi kualitas merupakan dimensi terpenting yang perlu diperhatikan untuk meningkatkan suatu kualitas informasi dibandingkan faktor-faktor lainnya.

\section{Kesimpulan}

Dengan menetapkan kepentingan relatif menggunakan AHP dan mengungkapkan dampak timbal balik dari dimensi IQ, kita dapat mengetahui bagaimana faktor kritis kualitas dari informasi yang buruk dapat digali secara objektif. Dalam penelitian ini, dimensi kualitas informasi pada website Kaskus yang harus diperbaiki adalah relevansi, kebenaran, dan objektivitas dengan beberapa faktor kritis kualitas: "informasi tidak dapat dipertanggungjawabkan", "informasi tidak konsisten", "informasi tidak dapat dipercaya" dan "Informasi tidak responsif".

Berdasarkan analisis dan penilaian, peneliti menyarankan sebuah layanan yang memberikan pilihan bagi setiap anggota untuk memberikan umpan balik (peringkat atau tanggapan) pada informasi yang mereka baca. Sehingga informasi yang tidak relevan, tidak benar, dan tidak bertanggungjawab di website Kaskus bisa segera diketahui oleh pembaca dan anggota lainnya juga bisa mengetahui apakah informasi yang mereka baca tersebut bermanfaat atau tidak.

Selain itu, peneliti juga menyarankan pihak management melakukan perbaikan dengan cara mencari tahu bagaimana hubungan/korelasi antar dimensi harus diperbaiki. Kemudian nilai korelasi yang sudah diketahui dimasukkan kembali ke dalam Quality Function Deployment (QFD) untuk dilakukan penilain ulang agar tujuan/arah tahap improve tetap akurat dan efektif. Selanjutnya setelah dilakukan tahap perbaikan dengan memasukkan kembali nilai korelasi ke dalam QFD, nilai akhir dari QFD (absolute importance) diterjemahkan ke dalam grafik $X$-bar Chart untuk memantau kualitas informasi dan memungkinkan adanya penilaian secara berkelanjutan. X-bar Chart juga dapat digunakan sebagai tolak ukur pengambilan keputusan management dalam menentukan strategi perusahaan kedepannya. 


\section{Daftar Pustaka}

Aziz, I., 2014. Jumlah Member Kaskus Tembus 7 Juta User. Aktual Post, page 11. http://www.aktualpost.com/2014/11/ jumlahmemberkaskus-tembus-7-juta-user.html diakses tanggal 15 November 2015.

Black, K., Revere, L., 2006. Six Sigma arises from the ashes of TQM with a twist. International Journal of Health Care Quality Assurance 19 (2/3), 25966.

Gardhadipura, A., 2015. Kronologis Singkat Tentang Kasus Rama. Kompasiana. http://www.kompasiana.com/ariagardhadipura/kr onologis-singkattentang-kasus, diakses tanggal 25 Desember 2015.

Gaspersz, V., 2011. Total Quality Management. Jakarta : Gramedia Pustaka Utama.

Grafelly, D., 2016. Path Tidak Bisa Diakses Karena Diretas Itu Berita Hoax. www.techno.id/social/path-tidak-bisa-diakseskarena-diretas-itu-berita-hoax-160304o.html diakses tanggal 4 Maret 2016.

Indrawati, 2015. Metode Penelitian Manajemen dan Bisnis Konvergensi Teknologi Komunikasi dan Informasi. (Cetakan 1). Bandung: PT. Refika Aditama.

Islam, R., Ahmed, M., Alias, M., 2007. Application of quality function deployment in redesigning website: A case study on TV3. Munich Personl RePEc Archive, II (2), 206.

Jamaludin, F., 2015. Kasus Penipuan Blackpanda, Kaskus Angkat Bicara. Merdeka. http://www.merdeka.com/teknologi/kasuspenipuan-blackpanda-kaskus-angkat-bicara.html diakses tanggal 25 Desember 2015.
Jeko I.R,, 2015. Raih 8 Juta User, Kaskus Ingin Gandeng Lebih.Banyak.Komunitas.. .http://tekno .liputan6.com/read/2223590/raih-8-juta-userkaskus-ingin-gandeng-lebih-banyak-komunitas, diakses tanggal 15 November 2015.

Kusumadewi, S., 2006. Fuzzy Multi-Attribute Decision Making (Edisi Pertama). Yogyakarta : Graha ilmu.

Kwak, Y.H., Anbari, F.T., 2006. Benefits, obstacles and future of Six Sigma approach, Technovation 26, 708-15.

Lee, S.H., Haider, A., 2011. A Framework for Informatin Quality Assessment Using Six Sigma 2011, Article ID 927907, 1-9.

Lee, S.H., Haider, A., Kim, J.G., Bahador, K.M.K., 2012. Information Quality Assessment in Korean Manufacturing Organization 23, 3-5.

Madnick, S. E., Wang, R. T., Lee, Y. W., Zhu, H., 2009. Overview and framework for data and information quality research. Journal of Data and Information Quality (JDIQ) 1 (1), 1-22.

Naumann, F., Rolker, C., 2000. Assessment methods for information quality criteria. Proceedings of the International Conference on Information Quality, Cambridge, MA.

Petter, S., DeLone, W., McLean, E., 2008. Measuring information systems success: models, dimensions, measures, and interrelationships. European Journal of Information Systems 17 (3). 236-263.

Jekaran, U., 2011. Research Methods for business Edisi I and 2. Jakarta: Salemba Empat

Sugiyono, 2010. Metode Penelitian pedidikan pendekatan kuantitatif, kualitatif, dan R\&D. Bandung: Alfabeta 